\title{
PENINGKATAN DAYA INGAT DAN HASIL BELAJAR SISWA DENGAN MIND MAPPING METHOD PADA MATERI LISTRIK DINAMIS
}

\author{
Rizki Annisa \\ Wawan Prasetyo Heryanto \\ Ani Rusilowati \\ Bambang Subali \\ Universitas Negeri Semarang \\ Semarang, Indonesia \\ E-mail: rizkiannisa22@gmail.com
}

\begin{abstract}
Abstrak
Metode mind mapping dalam penelitian ini bertujuan untuk meningkatkan daya ingat, hasil belajar, dan perhatian siswa mata pelajaran fisika materi listrik dinamis kelas IX MTs Al Futuhiyyah Bumirejo, Wonosobo. Sampel dalam penelitian ini adalah kelas IX Al Haitsam (A) berjumlah 25 siswa dengan nilai mata pelajaran fisika rata-rata di bawah KKM. Penelitian ini menggunakan Penelitian Tindakan Kelas (PTK) sebanyak 2 siklus. Masing-masing siklus terdiri dari tahap perencanaan, pelaksanaan, pengamatan, dan refleksi yang mengadopsi model Kurt Lewin. Daya ingat siswa dapat diketahui dengan membuat mind mapping, hasil belajar diperoleh dengan tes uraian, dan perhatian belajar didapatkan dari observasi. Hasil penelitian menunjukan bahwa: 1) penggunaan metode mind mapping dapat meningkatkan daya ingat siswa kelas IX MTs Al Futuhiyyah dari $38 \%$ menjadi $68 \%$, 2) penggunaan metode mind mapping dapat meningkatkan hasil belajar siswa kelas IX MTs Al Futuhiyyah dengan siswa yang mecapai KKM dari 36\% menjadi $56 \%$, 3) penggunaan metode mind mapping dapat memfokuskan perhatian dalam proses belajar siswa kelas IX MTs Al Futuhiyyah dengan persentase siswa $72 \%$.
\end{abstract}

Kata Kunci: daya ingat, hasil belajar, mind mapping, dan perhatian siswa.

\begin{abstract}
Mind Mapping method in this research purposed to improve memory, learning result, and students' attention to study physics with dynamic electricity subject 9th grade student of MTs Al Futuhiyyah Bumirejo, Wonosobo. Sample in this research are 9th grade of Al Haitsam (A) amount 25 students with physics subject score under KKM. The research using Action Research (PTK) as much as two Cycles. Each cycle based on planning step, acting, observing, and reflecting it refers to Kurt Lewin model. The students' memory are able to be known by mind mapping, The study result are obtained by description test, and The study attention are obtained from observation. The result of the study indicated that: 1) the use of mind mapping method could improve memory of the 9th grade student MTs Al Futuhiyyah from $38 \%$ became $68 \%, 2$ ) the use of mind mapping method could improve the result learning of 9th grade student of MTs Al Futuhiyyah. It can be seen from the student who surpassed KKM from $36 \%$ became $56 \%$, 3) the use of mind mapping method is appropriate to get students attention in teaching and learning process with percentage $72 \%$.
\end{abstract}

Keyword: memory, result study, mind mapping, and students' attention.

\section{PENDAHULUAN}

Observasi dan wawancara yang dilakukan di MTs Al Futuhiyyah Bumirejo, menunjukan bahwa hasil belajar siswa yang berupa nilai harian pertama (UH 1) pada materi sebelumnya hanya 9 siswa yang tuntas dari 25 siswa atau $36 \%$. Pada saat guru menjelaskan materi fisika, ada siswa yang memperhatikan dan ada yang kurang memperhatikan, hal ini berdasarkan hasil observasi dengan persentase $44 \%$ siswa yang memperhatikan. Selain itu, $76 \%$ siswa menyatakan lupa dari materi bab pertama yang baru diajarkan minggu sebelumnya, sehingga dapat dikatakan siswa memiliki daya ingat terhadap materi. Hal ini terjadi karena metode mengajar yang digunakan guru tidak melibatkan sisi 
kreatif atau belahan otak kanan siswa, sehingga pelajaran fisika tersebut menjadi kurang menarik untuk dipelajari bagi siswa. Pada saat dilakukan wawancara dengan guru fisika kelas IX MTs Al Futuhiyyah Bumirejo terdapat beberapa permasalahan, salah satu permasalahan yang sering terjadi adalah rendahnya hasil belajar siswa saat mengikuti ujian.

Menurut Nurhayati (2017) hasil belajar merupakan hasil yang dicapai seseorang setelah belajar yang ditandai dengan adanya perubahan pada diri orang tersebut. Perubahan yang dimaksud adalah perubahan tingkat hasil belajar dan penguasaan. Hasi belajar memiliki hubungan yang erat dengan daya ingat dan perhatian siswa, sehingga hasil belajar dapat dikatakan sebagai efek dari proses mengingat dan perhatian yang ditunjukkan saat proses belajar berlangsung. Dalam observasi yang kami lakukan, ingatan siswa terhadap materi dan pehatian siswa saat proses pembelajaran menjadi fokus permasalahan yang terdapat di kelas. Untuk mengukur hasil belajar harus sesuai dengan tujuan pencapaian kognitif yang disesuaikan dengan kemampuan peserta didik. Rendahnya hasil belajar siswa dapat disebabkan karena kurangnya pemahaman siswa. Hal ini dapat diakibatkan oleh beberapa faktor, faktor yang sangat mempengaruhi adalah siswa yang berasumsi bahwa mereka sudah mengerti materi fisika yang telah diajarkan pada proses belajar mengajar di dalam kelas berlangsung, siswa malu atau takut untuk bertanya saat tidak jelas dalam proses belajar mengajar, dan daya ingat siswa yang lemah (pelupa). Sehingga diperlukan suatu metode dalam kegiatan pembelajaran yang dapat meningkatkan daya ingat dan hasil belajar siswa pada materi fisika.

Metode mind mapping dapat digunakan dalam kegiatan pembelajaran untuk meningkatkan daya ingat siswa. Hal ini sesuai dengan penelitian Radina and Hamid (2016), model pembelajaran mind mapping adalah cara kreatif bagi peserta didik secara individual maupun kelompok untuk mencatat pelajaran dan menghasilkan ide-ide. Ide-ide yang dihasilkan akan dituangkan dalam bentuk peta pemikiran memungkinkan siswa untuk lebih mudah mengingat materi. Otak akan terlatih untuk berfikir secara teratur dan seimbang dengan menggunakan otak kiri dan otak kanan.

Menurut Fauzia and Purwantoyo (2015) penggunaan mind mapping dinilai sebagai pemicu bagi siswa yang kurang aktif di dalam kelas menjadi aktif dengan alat belajar miliknya sendiri, sehingga dapat meningkatkan kemampuan berfikir dan mengingat materi. Ketuntasan siswa tergolong tinggi, hal ini menunjukkan bahwa strategi mencatat kreatif mind mapping berhasil meningkatkan daya ingat siswa. Penelitian Imaduddin and Utomo (2012); Permatasari, Hadiarti, and Fadhilah (2017) juga menunjukkan bahwa penerapan media mind mapping mampu meningkatkan kemampuan daya ingat siswa pada materi yang diajarkan. Selain itu penelitian Putri (2013) penerapan metode mind map untuk meningkatkan kemampuan mengingat siswa pada mata pelajaran Ilmu Pengetahaun Sosial (IPS) kelas V SDN Kendal Sewu Tarik Sidoarjo.
Metode mind mapping juga dapat digunakan dalam kegiatan pembelajaran untuk meningkatkan hasil belajar siswa pada materi fisika. Hal ini sesuai dengan penelitian Widiana and Jampel (2016) yang menyatakan pendekatan pengajaran Multiple Intelligence yang dibantu oleh pemetaan pikiran (mind mapping), siswa dapat mengatur pengetahuan secara sistematis, memudahkan siswa memahami materi, membantu siswa dalam mempresentasikan hasil kerja dalam diskusi, dapat membuat kesimpulan tentang pelajaran, dan peningkatan prestasi belajar sains.

Menurut Imaduddin and Utomo (2012) penggunaan metode mind mapping dalam proses KBM pelajaran fisika lebih efektif dibandingkan dengan metode konvensional dalam peningkatan prestasi belajar fisika. Penelitian Permatasari et al. (2017) juga menunjukkan adanya peningkatan hasil belajar siswa menggunakan dengan mind mapping.

\section{METODE}

Penelitian ini menggunakan jenis penelitian tindakan kelas (Classroom Action Research). Pada penelitian ini menggunakan pendekatan yang bersifat deskriptif. Penggunaan pendekatan ini disesuaikan dengan tujuan pokok penelitian, yaitu untuk mengetahui peningkatan daya ingat, hasil belajar, dan perhatian belajar siswa dengan menerapkan mind mapping method. Sampel penelitian ini adalah siswa kelas IX MTs Al Futuhiyyah Bumirejo yang berjumlah 25 siswa. Instrumen penelitian adalah alat atau fasilitas yang digunakan peneliti dalam mengumpulkan data agar pekerjaannya lebih mudah dan hasilnya lebih baik, lebih cermat, lengkap, dan sistematis sehingga lebih mudah diolah (Arikunto, 2009).

Instrumen yang digunakan yaitu lembar observasi, tes uraian, dan lembar kerja mind mapping. Lembar observasi untuk mengetahui tingkat perhatian peserta didik saat proses belajar fisika, tes uraian untuk mengetahui peningkatan hasil belajar peserta didik, dan lembar kerja mind mapping untuk mengetahui tingkat daya ingat peserta didik.

Pelaksanaan penelitian mengikuti tahap-tahap penelitian tindakan kelas yang pelaksanaan tindakannya terdiri atas dua siklus. Model penelitian menggunakan model PTK Kurt Lewin sebagaimana yang dikutip oleh Sarwi and Rusilowati (2013) yang mengajukan empat komponen pokok yaitu perencanaan (planning), tindakan pelaksanaan (acting), pengamatan (observing), dan refleksi (reflecting).

Perencanaan menunjuk pada kegiatan merencanakan sesuatu yang disengaja dilakukan dengan tujuan tertentu. Perencanaan pada penelitian ini yaitu mengidentitifikasi masalah, analisis penyebab masalah, dan pengembangan bentuk pemecahan masalah. Tindakan pelaksanaan menunjuk pada kegiatan kelas yang dilakukan setelah apa yang sudah direncanakan. Pengamatan menunjuk pada sebuah kegiatan mengamati proses terjadinya tindakan kelas. Refleksi menunjuk pada proses menganalisis hasil data yang diperoleh. 
Keterkaitan keempat komponen tersebut dapat dipandang sebagai suatu siklus yang disajikan pada Gambar 1.

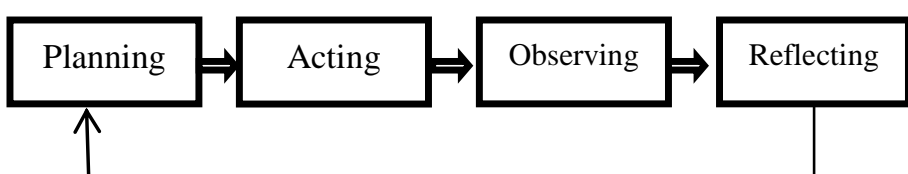

Gambar 1 Tahap Kegiatan penelitian tiap siklus pada penelitian tindakan

Kegiatan perencanaan peningkatan daya ingat, hasil belajar, dan perhatian belajar siswa dengan mind mapping method menggunakan tahapan-tahapan siklus yang berjenjang.

\section{Siklus I}

Langkah-langkah yang dilakukan dalam tahap perencanaan (planning) ini mencakup penentuan materi fisika yang akan menjadi materi dalam penelitian, penyusunan rencana pelaksanaan pembelajaran (RPP) dan menyiapkan modul untuk materi yang akan diajarkan. Setelah itu, peneliti menyiapkan sumber belajar berupa materi diskusi dan skenario pembelajaran dengan menggunakan mind mapping serta menyusun soal uraian untuk pretest dan postest beserta pedoman penskoran yang akan diterapkan dalam pelaksanaan penelitian ini.

Tahapan kedua adalah tahap tindakan pelaksanaan (acting). Tahapan tindakan pelaksanaan pada siklus I yaitu: guru menyampaikan apersepsi dan motivasi siswa dalam mempelajari materi listrik dinamis dan menunjukkan tujuan pembelajaran yang akan dicapai, guru membagi siswa dalam 5 (lima) kelompok dan menyampaikan materi pelajaran mengenai listrik dinamis dengan modul sebagai bahan belajar siswa. Siswa mengerjakan soal pretest untuk mengetahui kemampuan awal siswa. Guru memberi kesempatan kepada siswa untuk mengumpulkan informasi materi kepada setiap kelompok dengan memanfaatkan tutor sebaya serta bimbingan guru. Guru memastikan pemahaman siswa dengan memberikan kesempatan bertanya kepada siswa. Setelah berdiskusi siswa membuat mind mapping secara individu.

Tahapan ketiga adalah tahap pengamatan (observing). Dalam tahapan ini, peneliti melakukan observasi kegiatan siswa untuk mengetahui perhatian siswa dalam kegiatan pembelajaran. Tahapan terakhir pada siklus I adalah tahap refleksi (reflecting). Tahap refleksi untuk mengevaluasi hasil tes posttest dan perubahan yang terjadi sebagai dampak tindakan yang dilaksanakan. Apabila hasil refleksi sudah tercapai sesuai indikator keberhasilan yang direncanakan, maka penelitian berhenti pada siklus I, akan tetapi, apabila belum tercapai sesuai indikator keberhasilan, maka perlu dilanjutkan pada siklus ke II.

\section{Siklus II}

Hasil refleksi yang diperoleh pada tahap 1 belum sesuai indikator keberhasilan yang diharapkan, maka diadakan penelitian siklus kedua. Tahap pelaksanaan pada siklus II, proses pembelajarannya lebih fokus kepada siswa. Guru hanya menyampaikan materi secara umum dan siswa mendiskiusikan materi tersebut dengan mengacu pada modul dan buku paket IPA terpadu kelas IX.

\section{HASIL DAN PEMBAHASAN}

Data yang diperoleh dalam penelitian ini berupa data kualitatif dan data kuantitatif. Data kualitatuf terdiri dari hasil mind mapping siswa, observasi, dan dokumentasi yang menggambarkan kegiatan pembelajaran di kelas, sedangkaan data kuantitatif diperoleh dari penilaian hasil belajar siswa.

\section{a. Daya Ingat Siswa}

Peningkatan daya ingat siswa dapat dilihat pada Gambar 2 berikut:

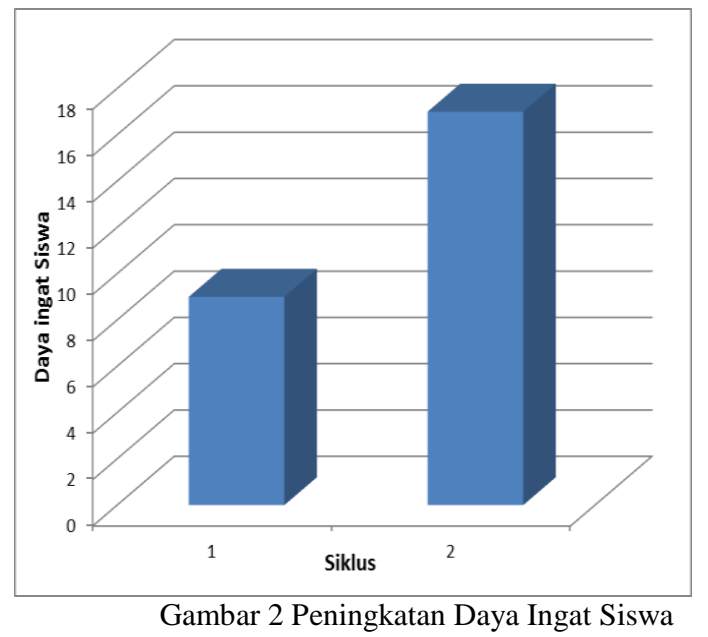

Hasil peningkatan daya ingat siswa berdasarkan kemampuan dalam membuat mind mapping. Siklus I jumlah siswa yang dapat mengingat sesuai dengan isi materi pelajaran adalah 9 siswa dengan persentase sebesar 36\%. Hal ini belum mencapai target indikator keberhasilan, sehingga dilanjutkan pada siklus ke II yang mengacu pada penyebab ketidaksesuaian siswa dalam membuat mind mapping pada siklus I. Hai ini disebabkan penggunaan metode mind mapping yang masih dianggap baru oleh siswa sehingga sebagian besar siswa bingung dalam membuat mind mapping.

Siklus II jumlah siswa yang dapat mengingat sesuai dengan isi materi pelajaran adalah 17 siswa dengan persentase sebesar $68 \%$, hal ini mengalami peningkatan sejumlah 8 siswa dengan persentase sebesar $32 \%$. Hasil peningkatan tersebut menunjukkan bahwa penggunaan metode mind mapping mampu meningkatkan kemampuan daya ingat siswa pada materi yang diajarkan. Hal ini sesuai dengan penelitian (Fauzia \& Purwantoyo, 2015; Permatasari et al., 2017; Radina \& Hamid, 2016) yang menyatakan bahwa metode mind mapping mampu meningkatkan kemampuan daya ingat siswa pada materi yang diajarkan.

\section{b. Hasil Belajar Siswa}

Peningkatan hasil belajar siswa dapat dilihat pada Gambar 3 berikut: 


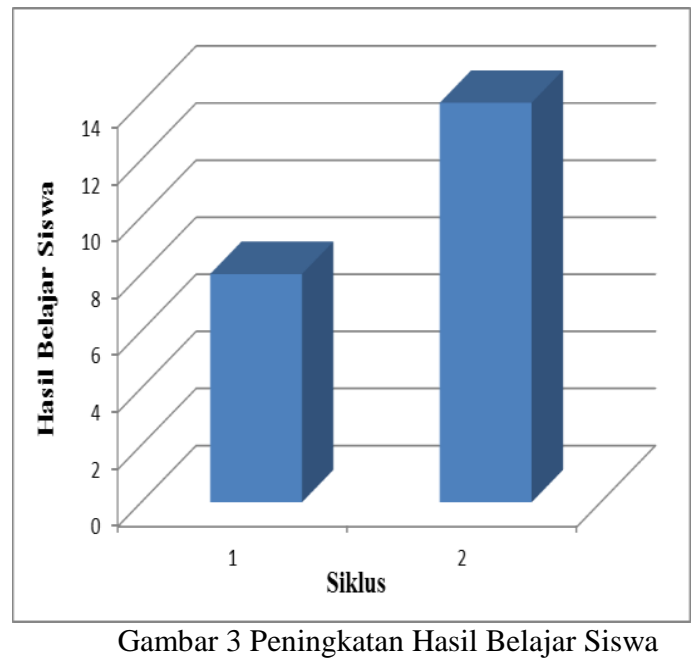

Peningkatan hasil belajar siswa berdasarkan nilai yang diperoleh siswa pada posttest. Jumlah siswa pada Siklus I yang mencapai KKM (75) adalah 8 siswa dengan persentase sebesar 32\%, Hal ini belum mencapai target indikator keberhasilan, sehingga dilanjutkan pada siklus II yang mengacu pada penyebab ketidaksesuaian disiklus I. Hal ini disebabkan proses penyampaian materi masih berpusat pada guru.

Siswa yang mencapai KKM pada siklus II berjumlah 14 siswa dengan persentase sebesar $56 \%$, hal ini menunjukan persentase peningkatan sebesar $24 \%$, yang artinya bahwa pennggunaan metode mind mapping mampu meningkatkan kemampuan hasil belajar siswa pada materi yang diajarkan. Hal ini sesuai dengan penelitian Permatasari et al. (2017); Widiana and Jampel (2016) yang menyatakan bahwa penggunaan metode mind mapping dalam proses KBM pelajaran fisika lebih efektif dibandingkan dengan metode konvensional dalam peningkatan prestasi belajar fisika.

\section{c. Perhatian Siswa}

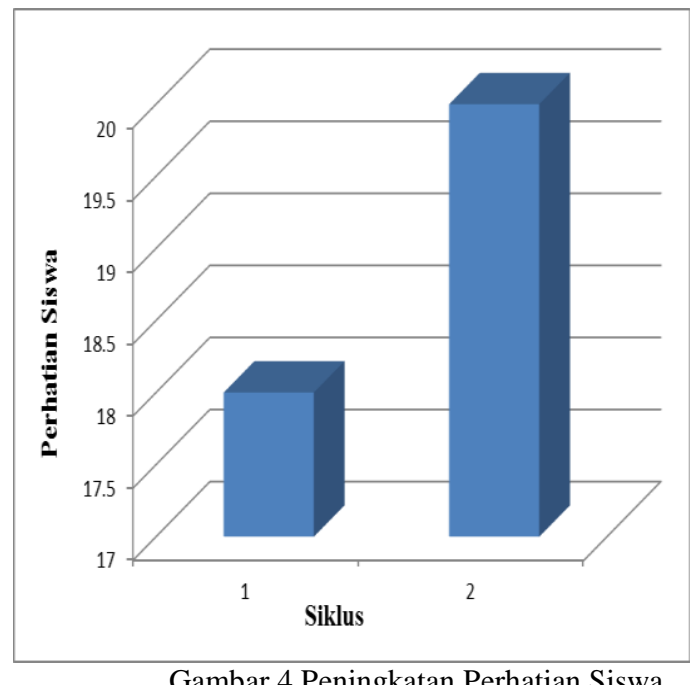

Hasil pengamatan untuk mengetahui perhatian siswa dalam belajar fisika menggunakan metode mind mapping dapat dilihat pada Gambar 4. Hasil observasi sebelum pemberian tindakan kelas menunjukkan bahwa pembelajaran masih berpusat pada guru, sehingga siswa kurang memperhatikan dan antusias mengikuti penjelasan yang diberikan oleh guru. Siswa yang memperhatikan saat proses pembelajaran pada siklus I berjumlah 18 siswa dengan persentase sebesar $72 \%$. Sedangkan pada siklus II jumlah siswa yang memperhatikan bertambah menjadi 20 siswa dengan persentase sebesar $80 \%$. Hal ini sudah mencapai target indikator keberhasilan.

Tabel 1 Persentase Keseluruhan

\begin{tabular}{|c|c|c|c|c|c|}
\hline \multirow{3}{*}{ No } & \multirow{3}{*}{$\begin{array}{c}\text { Jenis } \\
\text { Penilaian }\end{array}$} & \multirow{3}{*}{$\begin{array}{l}\text { Sebelum } \\
\text { CAR }\end{array}$} & \multirow{2}{*}{\multicolumn{2}{|c|}{$\begin{array}{c}\begin{array}{c}\text { Setelah } \\
\text { CAR }\end{array} \\
\text { Siklus }\end{array}$}} & \multirow{3}{*}{$\begin{array}{l}\text { Indikator } \\
\text { Keberhasilan }\end{array}$} \\
\hline & & & & & \\
\hline & & & 1 & 2 & \\
\hline 1 & $\begin{array}{l}\text { Daya ingat } \\
\text { siswa }(\%)\end{array}$ & 20 & 36 & 68 & 60 \\
\hline 2 & $\begin{array}{c}\text { Hasil } \\
\text { belajar }(\%)\end{array}$ & 20 & 32 & 56 & 50 \\
\hline 3 & $\begin{array}{l}\text { Perhatian } \\
\text { siswa }(\%)\end{array}$ & 40 & 72 & 80 & 70 \\
\hline
\end{tabular}

Tabel 1 adalah hasil persentase keseluruhan sebelum dilakukan tindakan kelas, sesudah tindakan kelas, dan indikator keberhasilan yang dibuat.

\section{PENUTUP}

Berdasarkan hasil penelitian dan analisis data yang dilakukan, maka dapat disimpulkan: (1) Penggunaan metode mind mapping dapat meningkatkan daya ingat siswa kelas IX MTs Al Futuhiyyah Bumirejo dari 38\% menjadi 68\%, (2) Penggunaan metode mind mapping dapat meningkatkan hasil belajar siswa kelas IX MTs Al Futuhiyyah Bumirejo dengan siswa yang mecapai KKM dari $36 \%$ menjadi 56\%, (3) Penggunaan metode mind mapping dapat memfokuskan perhatian dalam proses belajar siswa kelas IX MTs Al Futuhiyyah Bumirejo dengan persentase siswa $72 \%$.

Berdasarkan kesimpulan di atas, maka saran yang diberikan sebagai berikut: saat menggunakan metode mind mapping, sebaiknya guru dalam penyampaian materi lebih berpusat pada siswa. Siswa sebaiknya lebih aktif dalam berdiskusi dan kreatif dalam membuat mind mapping sesuai isi materi.

\section{DAFTAR PUSTAKA}

Arikunto, S. (2009). Dasar-dasar evaluasi pendidikan. Jakarta: Bumi Aksara.

Fauzia, M. Y., \& Purwantoyo, E. (2015). Efektivitas Strategi Mencatat Kreatif Mind Mapping untuk Meningkatkan Daya Ingat Siswa SMP Islam Cepu pada Materi Keanekaragaman Makhluk Hidup. Journal of Biology Education, 4(2).

Imaduddin, M. C., \& Utomo, U. H. N. (2012). Efektifitas Metode Mind Mapping untuk Meningkatkan Prestasi Belajar Fisika pada Siswa Kelas VIII. HUMANITAS: Indonesian Psychological Journal, 9(1), 62-75. 
Nurhayati, N. (2017). Upaya Meningkatkan Hasil Belajar Fisika Melalui Model Mind Mapping Pada Siswa Kelas $\mathrm{X}$ Mas Kapita Kabupaten Jeneponto. JPF: JURNAL PENDIDIKAN FISIKA, 2(1), 46-54.

Permatasari, T. P., Hadiarti, D., \& Fadhilah, R. (2017). Efektivitas Media Mind Map Berbasis Metode Latihan Berjenjang Terhadap Hasil dan Retensi Belajar Siswa Pada Materi Konsep Mol Di Kelas X SMA Negeri 8 Pontianak. AR-RAZI Jurnal Ilmiah, 5(2).

Putri, E. W. S. (2013). Penerapan Metode Mind Map Untuk Meningkatkan Kemampuan Mengingat di Sekolah Dasar. Jurnal Penelitian Pendidikan Guru Sekolah Dasar, 1(2).

Radina, A., \& Hamid, A. (2016). Penerapan Model Mind Mapping Berbasis Media Mindjet Mindmanager untuk Meningkatkan Hasil Belajar Siswa pada Materi Analisis Vektor untuk Gerak di Sman 12 Banda Aceh. Jurnal Ilmiah Mahasiswa Pendidikan Fisika, 1(4), 188-195.

Sarwi, \& Rusilowati, A. (2013). Penelitian Kependidikan: Teori dan Aplikasinya: Semarang: UNNES Press.

Suharsini, A. (1999). Dasar-dasar evaluasi pendidikan: Bumi Aksara.

Widiana, I. W., \& Jampel, I. N. (2016). Improving Students' Creative Thinking and Achievement through The Implementation of Multiple Intelligence Approach with Mind Mapping. International Journal of Evaluation and Research in Education (IJERE), 5(3), 246-254. 